\title{
Breast carcinoma and Lynch syndrome: molecular analysis of tumors arising in mutation carriers, non-carriers, and sporadic cases
}

\author{
Johanna E Lotsari ${ }^{1 *}$, Annette Gylling ${ }^{1}$, Wael M Abdel-Rahman ${ }^{1,2}$, Taina T Nieminen', Kristiina Aittomäki \\ Marjukka Frimann ${ }^{4}$, Reino Pitkänen ${ }^{4}$, Markku Aarnio ${ }^{5}$, Heikki J Järvinen ${ }^{6}$, Jukka-Pekka Mecklin ${ }^{5}$, Teijo Kuopio ${ }^{4}$ and \\ Päivi Peltomäki ${ }^{1}$
}

\begin{abstract}
Introduction: Breast carcinoma is the most common cancer in women, but its incidence is not increased in Lynch syndrome (LS) and studies on DNA mismatch repair deficiency (MMR) in LS-associated breast cancers have arrived at conflicting results. This study aimed to settle the question as to whether breast carcinoma belongs to the LS tumor spectrum.

Methods: MMR status and epigenetic profiles were determined for all available breast carcinomas identified among 200 LS families from a nation-wide registry (23 tumors from mutation carriers and 18 from non-carriers). Sporadic breast carcinomas $(n=49)$ and other cancers $(n=105)$ from MMR gene mutation carriers were studied for comparison.

Results: The proportion of breast carcinomas that were MMR-deficient based on absent MMR protein, presence of microsatellite instability, or both was significantly $(P=0.00016)$ higher among breast carcinomas from mutation carriers $(13 / 20,65 \%)$ compared to non-carriers $(0 / 14,0 \%)$. While the average age at breast carcinoma diagnosis was similar in carriers (56 years) and non-carriers (54 years), it was lower for MMR-deficient versus proficient tumors in mutation carriers (53 years versus 61 years, $P=0.027$ ). Among mutation carriers, absent MMR protein was less frequent in breast carcinoma (65\%) than in any of seven other tumor types studied (75\% to 100\%). Tumor suppressor promoter methylation patterns were organ-specific and similar between breast carcinomas from mutation carriers and non-carriers.

Conclusions: Breast carcinoma from MMR gene mutation carriers resembles common breast carcinoma in many respects (for example, general clinicopathological and epigenetic profiles). MMR status makes a distinction: over half are MMR-deficient typical of LS spectrum tumors, while the remaining subset which is MMR-proficient may develop differently. The results are important for appropriate surveillance in mutation carriers and may be relevant for LS diagnosis in selected cases.
\end{abstract}

\section{Introduction}

Germline mutation in one of four genes with DNA mismatch repair (MMR) function, $M L H 1, M S H 2, M S H 6$, and PMS2, causes susceptibility to cancers of multiple organs known as Lynch syndrome (LS) [1]. Among all cancers, those of the colon and rectum, endometrium,

\footnotetext{
* Correspondence: johanna.lotsari@helsinki.fi

'Department of Medical Genetics, Biomedicum Helsinki, P.O.Box 63 (Haartmaninkatu 8), University of Helsinki, Helsinki, Finland, FIN-00014 Full list of author information is available at the end of the article
}

small bowel, ureter and renal pelvis have the highest relative risk compared to the general population, which is why they are considered to be part of the LS tumor spectrum according to the Amsterdam criteria II [2]. Among extracolonic tumors accepted as LS spectrum tumors when the Amsterdam II criteria were formulated, cancer of the renal pelvis had the lowest relative risk (14) [3].

Breast cancer is the most common cancer among women worldwide [4]. It is presently not included in the

\section{Biomed Central}


LS tumor spectrum because its incidence has not been found to be elevated in LS patients, whether carriers of MLH1 or MSH2 mutation [5-8] or MSH6 mutation [9]. A few deviating reports exist. A study on Australian LS patients revealed a significantly increased standardized incidence ratio (14.77) for breast cancer in $M L H 1$, but not $\mathrm{MSH} 2$ mutation carriers [10]. The standardized incidence ratio for breast cancer was also elevated (3.95) in a prospective investigation of a cohort of 446 unaffected carriers of $M L H 1, M S H 2, M S H 6$, and PMS 2 mutation over a median follow-up of five years [11]. Furthermore, among Brazilian families meeting the most stringent clinical (Amsterdam I) criteria for LS [12] but with no mutation data available, breast cancer was the most frequent extracolonic cancer in women, even exceeding the frequency of endometrial cancer [13].

As an additional approach to decide whether breast cancer is a LS spectrum tumor or not, breast cancers arising in LS patients have been studied for microsatellite instability (MSI) or MMR protein expression since deficient MMR is a hallmark of LS. As observed originally, the absence of MMR defects appeared to exclude breast cancer as an integral tumor of LS [14] whereas subsequent studies report the occurrence of MMR defects in breast carcinomas from MMR gene mutation carriers with frequencies ranging between $44 \%$ and $75 \%$ based on MSI and/or aberrant MMR protein expression [8,15-19]. Frequencies of MMR defects reported in the latter studies exceed those independently observed for sporadic breast carcinomas (0 to 20\%) [20,21] suggesting that MMR deficiency is an important factor in breast cancer development in LS.

Given the conflicting results from previous studies, we collected all available LS-associated breast carcinomas through the nation-wide Hereditary Colorectal Cancer Registry of Finland. Molecular profiles in breast carcinomas from mutation carriers were compared to those from proven non-carriers (phenocopies) from mutationpositive families and to sporadic breast carcinomas from the same population; additionally, a large collection of other LS-associated tumors from mutation carriers was included in the analysis. Molecularly, breast carcinomas from LS mutation carriers were divided into two subgroups paralleled by some clinical differences (notably, different ages at onset) as will be described below.

\section{Materials and methods Patients and samples}

The more than 200 LS families currently included in the nation-wide Hereditary Colorectal Cancer Registry of Finland were evaluated to identify cases with breast cancer. All available breast tumors including 41 tumors from 37 individuals who belonged to families with $M L H 1, M S H 2$, or MSH6 mutations were subsequently collected (Table
1). Twenty-three breast tumors originated from 19 mutation carriers and included 11, five, and seven tumors from carriers of $M L H 1, M S H 2$, and MSH6 mutation, respectively (please see Table 2 for mutation descriptions). Eighteen breast tumors were obtained from 18 non-carriers who belonged to families with $M L H 1$ (15 tumors), $M S H 2$ (two tumors), and MSH6 mutations (one tumor). Four families contributed at least one breast cancer from a carrier and one from a non-carrier. Nine breast tumors originated from carriers of a prevalent founder mutation (mutation 1) [22] and the same predisposing mutation underlay the families of ten non-carriers with breast cancer. Forty-nine sporadic breast tumors, selected from a larger consecutive series to represent the two main histological types, ductal $(n=30)$ and lobular $(n=19)$, and to match the predominant hormone receptor status (positive) and human epidermal growth factor receptor 2 (HER2) status (negative) of LS-associated breast cancers were studied for comparison (Table 1). Additionally, existing data from 105 other tumors (including 33 from the colon and rectum, 38 from the endometrium, 13 from the stomach, five from the ureter, five from the bladder, four from the kidney, and seven from the brain) diagnosed in MMR gene mutation carriers were re-evaluated for MMR status and promoter methylation using criteria identical to those presently applied for breast cancer; detailed characteristics of the tumor series can be found in our previous publications [23-25].

DNA was extracted from formalin-fixed paraffinembedded tumor samples from selected areas with high tumor percentages according to the modified protocol of Isola et al. [26]. Normal breast tissue from the same patients was used for the extraction of normal DNA whenever possible. Additionally, to determine the baseline levels of methylation, normal breast tissues from a cohort of unrelated individuals were used as a source of DNA. For protein expression studies, $4 \mu \mathrm{l}$ sections from breast tumors were cut to glass adhesion slides (Thermo Scientific, Braunschweig, Germany) and air-dried overnight at $37^{\circ} \mathrm{C}$. The Institutional Review Boards of Helsinki University Central Hospital (Helsinki, Finland) and Jyväskylä Central Hospital (Jyväskylä, Finland) as well as the National Authority for Medicolegal Affairs (Dnro $1272 / 04 / 044 / 07)$ approved this study. All necessary consents were obtained from the patients involved.

\section{MSI analysis}

MSI statuses were analyzed using markers from the Bethesda panel [27]. In final interpretations, results from the mononucleotide markers (BAT25 and BAT26) were emphasized in that specimens with one or two unstable mononucleotide repeat markers were considered to have MSI whereas samples with stable mononucleotide repeats were regarded as microsatellite-stable (MSS). 
Table 1 Essential clinicopathological and molecular characteristics of the three breast cancer groups investigated.

\begin{tabular}{|c|c|c|c|}
\hline & $\begin{array}{l}\text { LS-associated breast } \\
\text { cancers }\end{array}$ & $\begin{array}{l}\text { LS-associated breast } \\
\text { cancers }\end{array}$ & \\
\hline & Carriers & Non-carriers & $\underset{c}{\text { Sporadic breast cancer }}$ \\
\hline No. of tumors & 23 & 18 & 49 \\
\hline ductal & 17 & 14 & 30 \\
\hline ductal in situ & 2 & 1 & - \\
\hline lobular & 3 & - & 19 \\
\hline other & 1 & 2 & - \\
\hline no histological data & - & 1 & - \\
\hline Size $(=20 \mathrm{~mm})$ & $7 / 19(37 \%)$ & $9 / 14(64 \%)$ & $30 / 49(61 \%)$ \\
\hline G1 & $2 / 19(11 \%)$ & $4 / 12(33 \%)$ & $12 / 46(26 \%)$ \\
\hline G2 & 10/19 (53\%) & $5 / 12(42 \%)$ & 29/46 (63\%) \\
\hline G3 & $7 / 19(37 \%)$ & $3 / 12(25 \%)$ & $5 / 46(11 \%)$ \\
\hline Lymph node metastases & $6 / 16(38 \%)$ & $7 / 10(70 \%)$ & $28 / 47(60 \%)$ \\
\hline \multicolumn{4}{|l|}{ Receptor status: } \\
\hline ER-positivity & 20/22 (91\%) & 6/7 (86\%) & $49 / 49(100 \%)$ \\
\hline PR-positivity & 15/22 (68\%) & $5 / 7(71 \%)$ & $41 / 46(89 \%)$ \\
\hline HER2-positivity & $3 / 20(15 \%)$ & $1 / 6(17 \%)$ & $0 / 49(0 \%)$ \\
\hline Average age at diagnosis (years) & 56 & 54 & 61 \\
\hline MSI & $8 / 23(35 \%)$ & $0 / 18(0 \%)$ & $\mathrm{N} / \mathrm{A}$ \\
\hline MMR protein reduced or lost & $13 / 20(65 \%)^{a}$ & $0 / 14(0 \%)^{b}$ & $0 / 49(0 \%)^{b}$ \\
\hline $\begin{array}{l}\text { Average number of TSGs methylated out of } 24 \text { per } \\
\text { tumor }\end{array}$ & 2.3 & 2.0 & 2.4 \\
\hline
\end{tabular}

${ }^{\mathrm{a}}$ For MMR protein corresponding to the germline mutation; ${ }^{\mathrm{b}}$ for any MMR protein investigated (MLH1, MSH2, MSH6); ${ }^{\mathrm{C}} \mathrm{Clinicopathological} \mathrm{data} \mathrm{and} \mathrm{MMR} \mathrm{status}$ reflect selection method used (see text). Note: All frequency calculations are based on tumors for which data were available or which could be successfully analyzed in the laboratory. ER, estrogen receptor; HER2, human epidermal growth factor receptor 2; LS, Lynch Syndrome; MMR, mismatch repair; MSI, microsatellite instability; PR, progesterone receptor; TSG, tumor suppressor gene.

\section{Immunohistochemical (IHC) staining for MMR protein expression}

Breast tumor tissue sections were stained with the following primary mouse antibodies: anti-MLH1 (clone: G168-15, BD Biosciences,/PharMingen, Erembodegem, Belgium) with dilution 1:60, anti-MSH2 (clone:FE11, Calbiochem,/Oncogene Research, Darmstadt, Germany) with dilution 1:80, and anti-MSH6 (clone:44/MSH6, BD Biosciences) with dilution 1:40. The immunohistochemical (IHC) reagents (Dako EnVision+, Dako, Glostrup, Denmark/Carpinteria CA, USA) were utilized according to the manufacturer's specifications. The microwave antigen-retrieval was performed at $750 \mathrm{~W}$ for five minutes and $450 \mathrm{~W}$ for five minutes in ethylenediaminetetraacetic acid (EDTA) buffer, pH8 (with MLH1 and MLH2 antibodies) and in citrate buffer, pH6 (with MLH6 antibody). The expression results were evaluated as described in Renkonen et al. [28].

\section{Methylation-specific multiplex ligation-dependent probe amplification (MS-MLPA)}

The methylation statuses of 24 tumor suppressor genes (TSGs) were analyzed by a commercial MS-MLPA test (SALSA MS-MLPA ME001-C1 Tumor suppressor-1,
MRC Holland, Amsterdam,The Netherlands) according to the manufacturer's instructions [29]. The 26 probe pairs included two probe pairs for $M L H 1$ of which only the one closest to the transcription start site (1686-L1266) was considered, and two probe pairs for RASSF1, where methylation was recorded if one or both showed methylation. DNA (200 ng to $500 \mathrm{ng}$ ) from paraffin-derived samples was used. Promega's human genomic female DNA (G152A, Madison WI, USA) was included as a normal reference in every assay. The MS-MLPA test utilizes the methylation sensitive enzyme Hha1 (Promega, R6441) which recognizes and digests a CpG site if it is unmethylated [30]. The methylated fraction of the sample will generate an amplified PCR product. The PCR products of individual probes are identified and quantified by capillary gel electrophoresis [31]. The fragment analysis was carried out on the Applied Biosystems ABI 3730 Automatic DNA Sequencer with Applied Biosystems GeneMapper 4.0 genotyping software. The methylation dosage ratios $\left(D_{m}\right)$ were calculated as described [24]. $D_{m} \geq 0.25$ (corresponding to at least $25 \%$ of methylated DNA) was considered to indicate promoter methylation. This cut-off value provided the best 
Table 2 MMR status and TSG promoter methylation results case by case for breast carcinomas from MMR gene mutation carriers

\begin{tabular}{|c|c|c|c|c|c|c|c|c|c|}
\hline \multirow[b]{2}{*}{$\begin{array}{l}\text { Case } \\
\text { ID }\end{array}$} & \multirow[b]{2}{*}{ Predisposing mutation } & \multirow[b]{2}{*}{ Histology } & \multirow[b]{2}{*}{$\begin{array}{l}\text { Age at } \\
\text { diagnosis }\end{array}$} & \multirow[b]{2}{*}{$\begin{array}{l}\text { MSI } \\
\text { status }\end{array}$} & \multicolumn{2}{|c|}{$\begin{array}{l}\text { MMR protein } \\
\text { expression }\end{array}$} & \multirow{2}{*}{ MSH6 } & \multirow[b]{2}{*}{$\begin{array}{l}\text { Overall } \\
\text { MMR } \\
\text { status }^{\mathrm{a}}\end{array}$} & \multirow[b]{2}{*}{$\begin{array}{l}\text { Average number of TSGs } \\
\text { methylated out of } 24 / \text { tumo }\end{array}$} \\
\hline & & & & & MLH1 & $\mathrm{MSH} 2$ & & & \\
\hline $2: 51$ & $\begin{array}{l}\text { MLH1 ex 16: } 3,5 \mathrm{~Kb} \text { deletion } \\
\text { (mutation I) }\end{array}$ & ductal in situ & 52 & MSI & - & + & + & abnormal & 1 \\
\hline 3:60 & $\begin{array}{l}\text { MLH1 ex 16: } 3,5 \mathrm{~Kb} \text { deletion } \\
\text { (mutation I) }\end{array}$ & ductal & 66 & MSS & + & + & + & normal & 2 \\
\hline 10:11 & $\begin{array}{l}\text { MLH1 ex 16: } 3,5 \mathrm{~Kb} \text { deletion } \\
\text { (mutation I) }\end{array}$ & ductal & 50 & MSS & - & + & ND & abnormal & 0 \\
\hline \multirow[t]{2}{*}{$50: 44$} & $\begin{array}{l}\text { MLH1 ex 16: } 3,5 \mathrm{~Kb} \text { deletion } \\
\text { (mutation I) }\end{array}$ & ductal, left breast & 71 & MSS & + & + & + & normal & 1 \\
\hline & & $\begin{array}{l}\text { lobular, right } \\
\text { breast }\end{array}$ & 72 & MSS & - & + & ND & abnormal & 4 \\
\hline $62: 1$ & $\begin{array}{l}\text { MLH1 ex 16: } 3,5 \mathrm{~Kb} \text { deletion } \\
\text { (mutation I) }\end{array}$ & ductal + in situ & 52 & MSI & - & ND & ND & abnormal & 3 \\
\hline \multirow[t]{2}{*}{ 77:15 } & $\begin{array}{l}\text { MLH1 ex 16: } 3,5 \mathrm{~Kb} \text { deletion } \\
\text { (mutation I) }\end{array}$ & $\begin{array}{l}\text { ductal, right } \\
\text { breast }\end{array}$ & 43 & MSI & - & + & + & abnormal & 0 \\
\hline & & $\begin{array}{l}\text { lobular, left } \\
\text { breast }\end{array}$ & 47 & MSS & - & + & ND & abnormal & 1 \\
\hline $77: 24$ & $\begin{array}{l}\text { MLH1 ex 16: } 3,5 \mathrm{~Kb} \text { deletion } \\
\text { (mutation I) }\end{array}$ & lobular & 51 & MSS & + & + & + & normal & 0 \\
\hline 143:1 & MLH1 c.454-1G>A, splice site & ductal & 56 & MSI & - & + & + & abnormal & 3 \\
\hline 157:1 & MLH1 c1489insC & ductal & 54 & MSI & - & + & + & abnormal & 4 \\
\hline 136:1 & MSH2 c.1738insA & ductal + in situ & 79 & MSS & ND & ND & ND & ND & 2 \\
\hline 180:1 & MSH2 del ex 1-16 & ductal & 60 & MSS & ND & ND & ND & ND & 1 \\
\hline \multirow[t]{2}{*}{ 191:1 } & $\begin{array}{l}\text { MSH2 ex1-7 deletion and } \\
\text { MEN1 mutation }\end{array}$ & $\begin{array}{l}\text { ductal, right } \\
\text { breast, small } \\
\text { tumor }\end{array}$ & 48 & MSI & + & - & - & abnormal & 2 \\
\hline & & $\begin{array}{l}\text { ductal, right } \\
\text { breast, large } \\
\text { tumor }\end{array}$ & 48 & MSI & + & - & - & abnormal & 4 \\
\hline 197:1 & MSH2 c.187delG & ductal & 55 & MSI & + & - & - & abnormal & 1 \\
\hline 132:1 & $\begin{array}{l}\text { MSH6 c.2983 G>T, nonsense } \\
\text { and CHEK2 c.1100delC }\end{array}$ & ductal in situ & 69 & MSS & + & ND & + & normal & 1 \\
\hline $132: 2$ & $\begin{array}{l}\text { MSH6 c.2983 G>T, nonsense } \\
\text { and CHEK2 c.1100delC }\end{array}$ & ductal & 35 & MSS & ND & ND & ND & ND & 1 \\
\hline \multirow[t]{2}{*}{ 196:1 } & MSH6 ex1-2 deletion & ductal, left breast & 52 & MSS & + & + & - & abnormal & 2 \\
\hline & & $\begin{array}{l}\text { ductal, right } \\
\text { breast }\end{array}$ & 56 & MSS & + & + & - & abnormal & 3 \\
\hline 196:2 & MSH6 ex1-2 deletion & ductal & 56 & MSS & + & + & + & normal & 2 \\
\hline $196: 3$ & MSH6 ex1-2 deletion & mucinous & 68 & MSS & + & + & + & normal & 2 \\
\hline $196: 4 b$ & MSH6 ex1-2 deletion & ductal & 49 & MSS & + & + & + & normal & 12 \\
\hline
\end{tabular}

${ }^{a}$ Abnormal MMR status denotes absence of MMR protein corresponding to the germline mutation, presence of MSI, or both. Normal MMR status requires intact MMR protein expression relative to germline mutation and stable microsatellites. NOTE: ND, not defined; for IHC, -, protein absent, +, protein present. IHC, immunohistochemistry; MMR, mismatch repair; MSI, microsatellite instability; TSG, tumor suppressor gene.

discrimination between tumor DNA and paired normal DNA in the present breast cancer series.

\section{Statistical analysis}

Programs from the VassarStats website [32] were used. The significance level for the differences between groups $(P$ value) was determined using Fisher's exact test or Student's t test as appropriate. $P$ values $<0.05$ (twotailed) were considered significant.

\section{Results}

Study design and clinicopathological characteristics This study was based on 90 breast carcinomas (23 from mutation carriers, 18 from non-carriers, and 49 from sporadic cases) (Table 1) and 105 other tumors from MMR gene mutation carriers (see Materials and methods for details). Most breast tumors from mutation carriers were ductal (17 out of 21 invasive tumors, 81\%), estrogen receptor (ER) positive (91\%), progesterone receptor (PR) 
positive (68\%) and HER2 negative (85\%) and the same was true for breast tumors from non-carriers. The hormone receptor and HER2 status of the LS-associated series resembled those in unselected breast carcinomas from our population [33]. The average age at diagnosis was similar in carriers (56 years) and non-carriers (54 years).

\section{MMR status}

Detailed molecular data on breast carcinomas from mutation carriers are shown in Table 2. MMR protein corresponding to the germline mutation was reduced or lost in $13 / 20(65 \%)$ and MSI was present in $8 / 23$ (35\%). Examples of positive and negative IHC and MSI results are given in Figure 1. The percentage of MMR-deficient breast carcinomas was lower among MSH6 mutation carriers $(2 / 6,33 \%$ by IHC and $0 / 7$ by MSI analysis) compared to carriers of $\mathrm{MSH} 2$ (3/3, $100 \%$ and $3 / 5,60 \%$, respectively) or $M L H 1$ mutation $(8 / 11,73 \%$ and $5 / 11,45 \%$, respectively) (statistically not significant). Breast carcinomas with abnormal MMR by IHC, MSI, or both were diagnosed at an earlier mean age compared to those with normal MMR (53 years versus 61 years, $P=0.027$ ). Abnormal MMR was significantly more frequent in breast carcinomas from mutation carriers than in those from non-carriers $(13 / 20,65 \%$ versus $0 / 14,0 \%, P=0.00016$ by Fisher's test) (Table 1).

\section{TSG promoter methylation}

Among 24 TSGs investigated, the average number of genes showing promoter methylation in breast carcinomas from mutation carriers was 2.3 per tumor, which was comparable to non-carriers and sporadic cases (Table 1). The most frequently methylated genes were RASSF1 (65\%), APC (43\%), CDH13 (35\%), GSTP1 (17\%), and $C D K N 2 B(17 \%)$, and the pattern was quite similar in breast carcinomas from mutation carriers, non-carriers and sporadic ductal cases (Figure 2). Ductal and lobular breast cancers showed some differences in relative frequencies of methylation at promoters of individual TSGs (Figure 2). In particular, CDKN2B methylation was more common in lobular than ductal breast carcinoma at a borderline level of significance (10/22, 45\% versus $14 / 64,22 \%$ with all groups included, $P=0.052$ by Fisher's test).

\section{Comparison of different tumors from MMR gene mutation carriers}

Evaluation of the MMR status in eight different tumor types from MMR gene mutation carriers showed that breast carcinoma had the lowest frequency of MMR protein inactivation and the second lowest frequency of MSI (Figure 3A). TSG promoter methylation revealed organ-specific profiles (Figure $3 \mathrm{~B}$ ). The top five genes affected by methylation in breast carcinoma were involved with variable frequencies in the other tumor

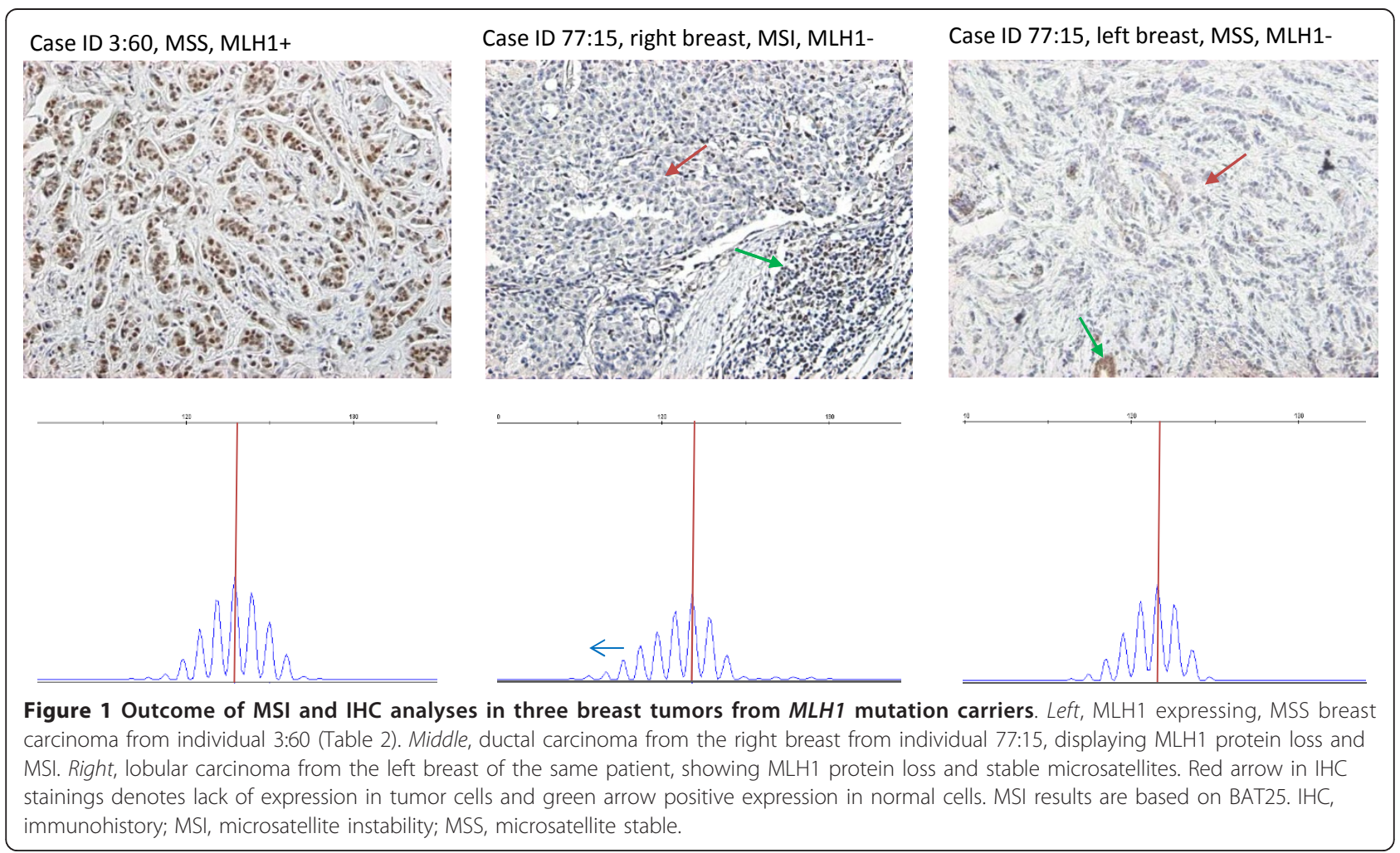




\section{$\%$ of tumors with methylation}
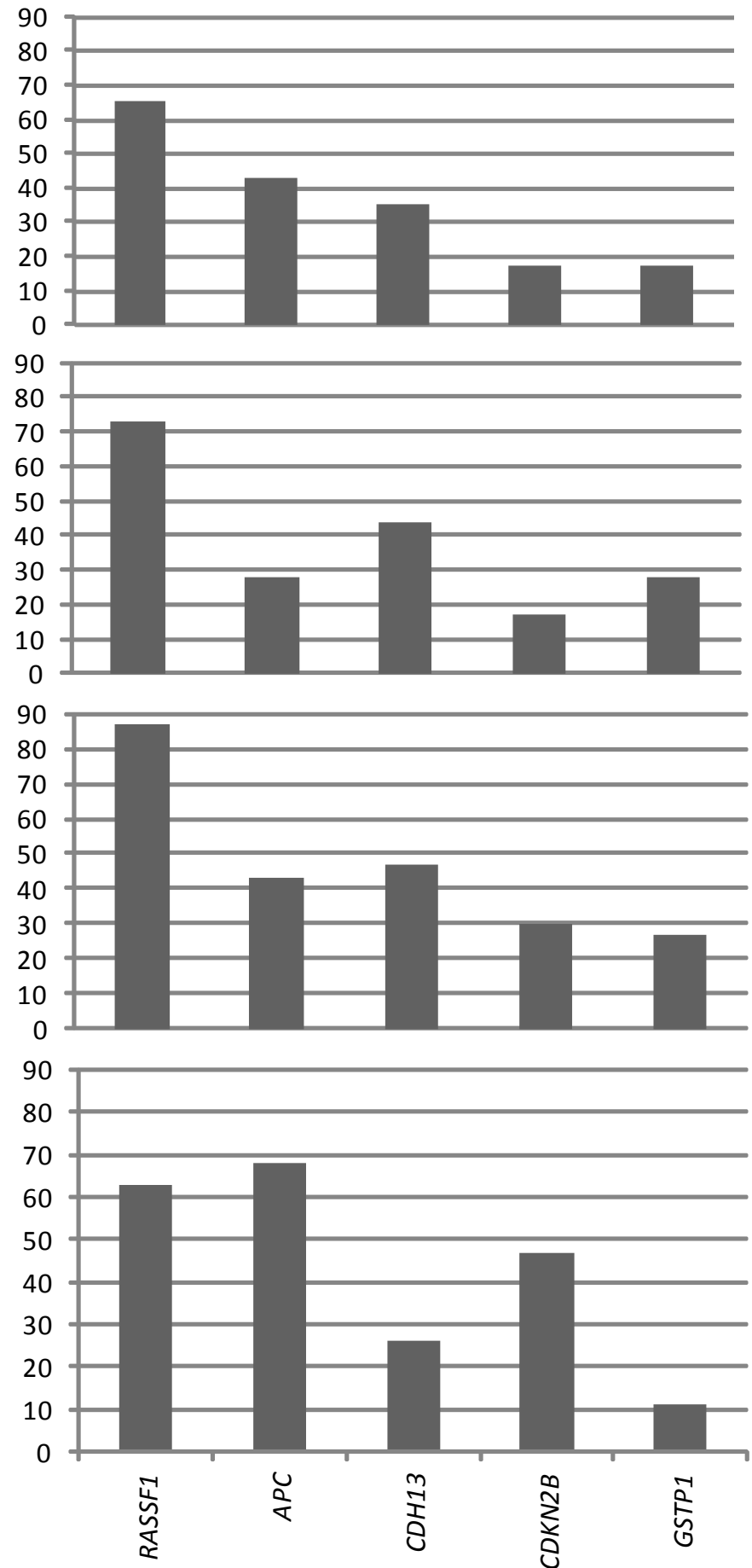

Figure 2 TSG methylation profiles in breast tumors from MMR gene mutation carriers, non-carriers and sporadic cases. Breast carcinomas from MMR gene mutation carriers and non-carriers were mostly ductal (Table 1) whereas sporadic cases were divided into ductal and lobular subgroups. Only TSGs which showed promoter methylation in at least 10\% of tumors from any group (carriers, non-carriers, sporadic) were included in this comparison. MMR, mismatch repair; TSG, tumor suppressor gene.

\section{LS - breast cancer from carriers $(n=23)$}

\section{LS - breast cancer from non-carriers $(n=18)$}

\section{Sporadic breast cancer, ductal $(n=30)$}

Sporadic breast cancer, lobular ( $n=19$ ) 
A

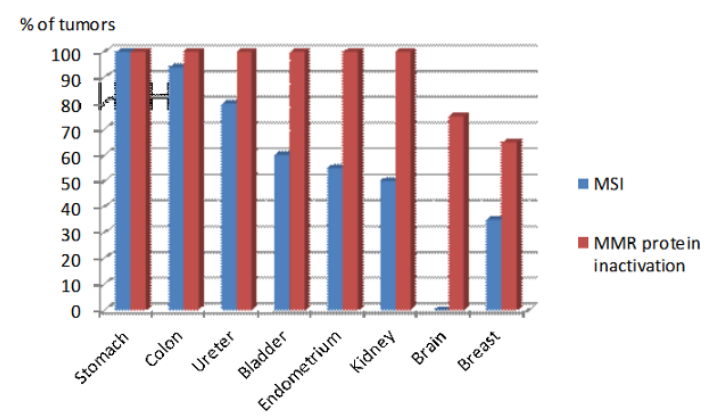

B

$\%$ of tumors with methylation
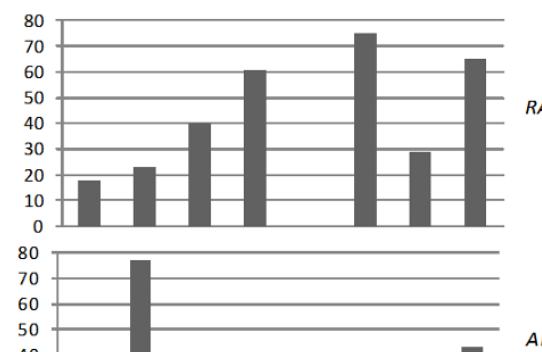

40

30

20
10
0

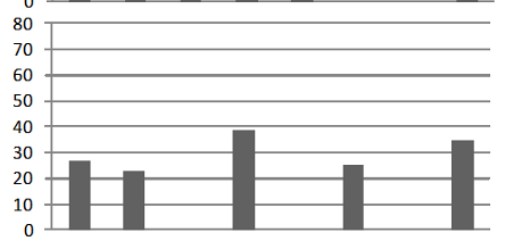

$A P C$

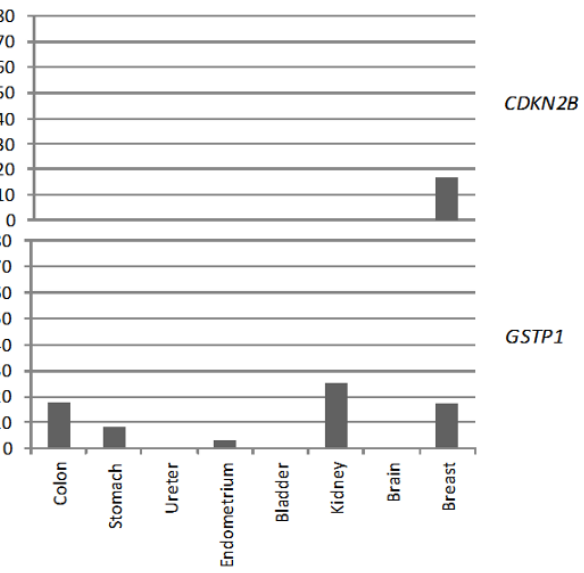

$\begin{array}{llllllll}2.5 & 3.3 & 0.8 & 1.5 & 0.4 & 1.3 & 1.3 & 2.3\end{array}$

Figures 3 MMR status and TSG methylation in eight different tumor types from mutation carriers. A, for MMR status comparisons, the frequencies of MSI and abnormal IHC in the same tumors are indicated. B, Among TSGs, the top five loci affected by methylation in breast cancer were chosen for display. Dm $\geq 0.25$ was used as a cut-off for methylation for all tumors. The average number of methylated TSGs out of 24 per tumor is given below each tumor type. Dm, methylation dosage ratio; IHC, immunohistochemistry; MMR, mismatch repair; MSI, microsatellite instability; TSG, tumor suppressor gene. 
types, too, except for $C D K N 2 B$ which was methylated in breast carcinoma only. In regard to the average number of methylated TSGs out of 24 per tumor, breast carcinoma (2.3) was the third from top (after 3.3 for stomach and 2.5 for colon cancer; Figure $3 \mathrm{~B}$ ).

\section{Discussion}

Genetic and clinical heterogeneity characterize LS and manifest themselves in the wide spectrum of cancers that can be found in LS families [1,34]. We set out to address whether breast carcinoma is part of the LS tumor spectrum based on molecular characteristics of the individuals and tumors. To our knowledge, our study is the first to compare breast carcinomas from mutation carriers to those from proven non-carriers (phenocopies) and to sporadic breast carcinomas from the same population. This setting provides a reliable reference for the background rates of the alterations examined. For example, many cancers that occur in LS are also common in the general population, reflecting the combined effect of low-penetrance susceptibility alleles and environmental factors [35]. Moreover, the pattern of organ involvement has changed over time including, for example, a relative decline in stomach cancer and an increase in colorectal cancer incidence in more recent generations [36] and may vary according to the ethnic or geographic origin $[13,37]$, suggesting that the LS tumor spectrum is sensitive to environmental influences. The present utilization of representative sets of other tumors from carriers of the same mutations additionally makes it possible to recognize the important role that the tissue of origin may play as a mediator of the effects of MMR deficiency [38] or epigenetic dysregulation [39]. Finally, previous molecular studies on LSassociated breast carcinoma have mainly focused on the MMR status; we additionally evaluated the epigenetic profiles of the tumors.

Our previous epidemiological investigation of MMR gene mutation carriers from Finnish LS families [5] arrived at a standardized incidence ratio of 1.4 for breast cancer compared to the general population, suggesting that breast cancer incidence is not elevated in Finnish LS families. This finding is in agreement with most reports from other populations (see Introduction). In the present study, breast carcinoma was diagnosed at 56 years of age in carriers and 54 years in non-carriers, which is comparable to sporadic breast carcinomas from our population (59 years) [33]. In the available literature, the average age of breast carcinoma diagnosis in MMR gene mutation carriers varies between 46 years and 66 years, including both early-onset series $[6,18,40]$ and series with the age at onset similar to the general population $[8,17]$. Interestingly, the age at diagnosis was significantly lower for MMR-deficient- (53 years) versus
MMR-proficient breast carcinomas (61 years) among mutation carriers from our study. Combined with the normal life-time risk of breast cancer in our LS families, the finding is compatible with the idea that MMR defects might preferentially be involved in breast cancer progression rather than initiation [6]. The breast carcinomas we studied from MMR gene mutation carriers were predominantly ductal, ER- and PR-positive and HER2-negative, resembling breast carcinomas from noncarriers (Table 1) and those from the unselected Finnish population $[33,41]$. Similar to our findings, ductal histology predominates in published reports on LS-associated breast carcinomas [17-19]. While the hormone receptor or HER2 status has seldom been specified in previous papers, a single study [19] found predominant hormone receptor negativity among MMR-deficient breast cancers from MMR gene mutation carriers; furthermore, there was no difference in the age at onset between MMRdeficient and MMR-proficient breast cancers. Apart from possible population-specific differences, reasons for the conflicting results relative to ours are unknown.

Apparent selectivity in tumor spectrum despite ubiquitous expression is a puzzle shared by a majority of high-penetrance susceptibility genes, including the MMR genes in LS. In theory, the LS tumor spectrum could be influenced by the predisposing gene and mutation (for example, carriers of $\mathrm{MSH} 2$ mutation may have a higher risk of various extracolonic tumors compared to $M L H 1$ mutation carriers [6]). MMR gene dosage, which affects the extent and degree of the MMR defect, is also important, both constitutionally (for example, biallelic germline mutations are associated with a distinct tumor spectrum characterized by hematological and central nervous system malignancies, [42]) and somatically (for example, DNA damage signaling requires a higher dosage of MMR protein than DNA mismatch repair [43] and inactivation of both alleles of a MMR gene may, therefore, not always be necessary in tumor cells). Different target genes are rate-limiting in different cancers and their susceptibility to mutations and selective advantage conferred by the mutations may vary (for example, TGFBRII and PTEN both contain coding repeats which are structurally prone to frameshift mutations in the context of deficient MMR, but TGFBRII is mainly involved in gastrointestinal cancers and PTEN in endometrial cancer [44]. Finally, different organs may be differently exposed to exogenous (for example, dietary carcinogens) or endogenous agents (for example, hormone-induced oxidative stress) and removal of such damage may depend on functional MMR [45,46].

In our study, 65\% (13/20) of breast carcinomas from MMR gene mutation carriers showed loss of the MMR protein corresponding to the germline mutation and 
$35 \%(8 / 23)$ had high-degree MSI. In comparison with other tumors from MMR gene mutation carriers, the percentage of breast carcinomas with MMR protein inactivation was consistently lower and the proportion with MSI-H in the lower range (Figure 3A). The fact that MSH6 mutations were overrepresented among patients with breast carcinomas $(7 / 23,30 \%)$ versus other tumors $(4 / 105,4 \%)$ might have some influence on the results since the percentage of MMR-deficient breast carcinomas was lower among MSH6 than MSH2 or MLH1 mutation carriers (Table 2). Importantly, we observed that a given MMR gene mutation could be associated with MMR proficient breast carcinomas in some carriers and MMR-deficient breast carcinomas in other carriers of the same mutation (see Table 2 and Figure 1 for examples), ruling out the possibility that normal protein expression or microsatellite-stability was a general characteristic of these mutations. We conclude that breast carcinomas from MMR gene mutation carriers conformed to other LS tumors in that IHC analysis of MMR protein expression was more sensitive than MSI analysis to detect a MMR defect but deviated from the remaining tumors in that even $\mathrm{IHC}$ failed to detect a MMR defect in a considerable proportion (35\%) arguing against biallelic inactivation in those cases. Even so, the proportion of MMR-deficient breast carcinomas was significantly higher compared to breast carcinomas from non-carriers (Table 1) suggesting that MMR defects do play a role in breast tumorigenesis in MMR gene mutation carriers. Furthermore, as discussed above, the possible role of MMR gene malfunction in processes other than MMR cannot be completely excluded in the case of MMR-proficient tumors.

The role of growth-regulatory target genes was addressed through studies of promoter methylation, which is known to be an important mechanism of inactivation of the TSGs examined [25,47]. The average number of methylated TSGs out of 24 was in the upper range in breast carcinomas among all tumors from MMR gene mutation carriers (Figure $3 \mathrm{~B}$ ). The five most frequently methylated TSGs (RASSF1, APC, CDH13, GSTP1, and $C D K N 2 B$ ) were the same in all groups of breast cancer (Figure 2) and, with the exception of $C D K N 2 B$, were involved in other tumors from LS patients, too, although with variable frequencies (Figure $3 \mathrm{~B})$. $C D K N 2 B$ promoter methylation may be a particular characteristic of breast tumorigenesis as also supported by observations from other groups [48].

\section{Conclusions}

Our findings combined with available literature suggest that breast carcinoma arising in MMR gene mutation carriers resembles common breast carcinoma with respect to life-time risk, clinicopathological features, and
TSG methylation profiles. Significantly higher frequencies of MMR-deficiency distinguish breast carcinomas from MMR gene mutation carriers from those from proven non-carriers and sporadic cases. The data as a whole suggest an association between breast cancer and inherited MMR deficiency (LS), but appropriate caution is warranted in interpretations because of the relatively small numbers of cases investigated and the variability between individual studies. Clinically, the results are important for the establishment of LS diagnosis especially in families lacking typical LS spectrum tumors; in such cases, IHC analysis of breast carcinoma may be valuable to pinpoint the predisposing gene. The fact that breast carcinoma may develop as a consequence of the predisposing MMR gene defect needs to be taken into account in the counseling of female MMR gene mutation carriers [49]. Mutation carriers should be encouraged to actively participate in population-based breast screening programs, which typically target women aged 50 years and over [50].

\section{Abbreviations}

APC: human adenomatous polyposis coli; $C D H 13$ : human cadherin $12 / \mathrm{H}-$ cadherin; CDKN2B: human cyclin-dependent kinase inhibitor 2B; Dm: methylation dosage ratio; ER: estrogen receptor; GSTP1: human glutathione S-transferase pi 1; HER2: human epidermal growth factor receptor 2; IHC: immunohistochemistry; MSS: microsatellite stable; LS: Lynch syndrome; MMR: mismatch repair; MLH1: human mutL homolog 1; MSH2: human mutS homolog 2; MSH6: human mutS homolog 6; MSI: microsatellite instability; MS-MLPA: methylation-specific multiplex ligation-dependent probe amplification; PCR: polymerase chain reaction; PMS2: human post meiotic segregation increased homolog 2; PR: progesterone receptor; PTEN: human phosphatase and tensin homolog; RASSF1: human ras association (RalGDS/ AF-6) domain family member -1; TGFBRIl: human transforming growth factor: beta receptor II; TSG: tumor suppressor gene.

\section{Acknowledgements}

We thank Katja Kuosa, Kirsi Pylvänäinen, Marjo Rajalaakso and Tuula Lehtinen for acquiring samples and data, and Saila Saarinen and Anni Tieva for assistance in the laboratory. This study was supported by the Helsink Graduate Program in Biotechnology and Molecular Biology (GPBM), the Academy of Finland, the Finnish Cancer Organizations, the Sigrid Juselius Foundation, Biocentrum Helsinki, and the European Research Council (FP7ERC-232635)

\section{Author details}

'Department of Medical Genetics, Biomedicum Helsinki, P.O.Box 63 (Haartmaninkatu 8), University of Helsinki, Helsinki, Finland, FIN-00014 ${ }^{2}$ College of Health Sciences, University of Sharjah, P.O. 27272 Sharjah, United Arab Emirates. ${ }^{3}$ Department of Clinical Genetics, Helsinki University Central Hospital, P. B. Box 160 (Meilahdentie 2), Helsinki, Finland, FIN-00029.

${ }^{4}$ Department of Pathology, Jyväskylä Central Hospital, (Keskussairaalantie 19), Jyväskylä, Finland, FIN-40620. ${ }^{5}$ Department of Surgery, Jyväskylä Central Hospital, (Keskussairaalantie 19), Jyväskylä, Finland, FIN-40620. ${ }^{6}$ Department of Surgery, Helsinki University Central Hospital, P.O Box 340 (Haartmaninkatu 4), Helsinki, Finland, FIN-00029.

\section{Authors' contributions}

JEL performed all methylation studies for breast tumors. AG conducted IHC analyses for breast tumors. AG, TTN, and JEL were responsible for MS analyses. TK, WA-R, RP and MF contributed to histological analyses of tissue specimens and evaluated $I H C$ results. J-PM, HJ, MA and KA diagnosed and recruited the Lynch syndrome cases and TK provided specimens from the 
sporadic cases. PP, J-PM, TK, and JEL conceived the study and drafted the manuscript. All authors read and approved the final manuscript.

\section{Competing interests}

The authors declare that they have no competing interests.

Received: 30 March 2012 Revised: 24 May 2012

Accepted: 12 June 2012 Published: 12 June 2012

\section{References}

1. Peltomaki P: Lynch syndrome genes. Fam Cancer 2005, 4:227-232.

2. Vasen HF, Watson P, Mecklin JP, Lynch HT: New clinical criteria for hereditary nonpolyposis colorectal cancer (HNPCC, Lynch syndrome) proposed by the International Collaborative group on HNPCC. Gastroenterology 1999, 116:1453-1456.

3. Watson P, Lynch HT: Extracolonic cancer in hereditary nonpolyposis colorectal cancer. Cancer 1993, 71:677-685.

4. Kamangar F, Dores GM, Anderson WF: Patterns of cancer incidence, mortality, and prevalence across five continents: defining priorities to reduce cancer disparities in different geographic regions of the world. J Clin Oncol 2006, 24:2137-2150.

5. Aarnio M, Sankila R, Pukkala E, Salovaara R, Aaltonen LA, de la Chapelle A, Peltomaki P, Mecklin JP, Jarvinen HJ: Cancer risk in mutation carriers of DNA-mismatch-repair genes. Int J Cancer 1999, 81:214-218.

6. Vasen HF, Morreau H, Nortier JW: Is breast cancer part of the tumor spectrum of hereditary nonpolyposis colorectal cancer? Am J Hum Genet 2001, 68:1533-1535.

7. Watson $\mathrm{P}$, Vasen HF, Mecklin JP, Bernstein I, Aarnio M, Jarvinen HJ, Myrhoj T, Sunde L, Wijnen JT, Lynch HT: The risk of extra-colonic, extraendometrial cancer in the Lynch syndrome. Int J Cancer 2008, 123:444-449.

8. Buerki N, Gautier L, Kovac M, Marra G, Buser M, Mueller H, Heinimann K: Evidence for breast cancer as an integral part of Lynch syndrome. Genes Chromosomes Cancer 2012, 51:83-91.

9. Baglietto L, Lindor NM, Dowty JG, White DM, Wagner A, Gomez Garcia EB, Vriends AH, Dutch Lynch Syndrome Study Group, Cartwright NR, Barnetson RA, Farrington SM, Tenesa A, Hampel H, Buchanan D, Arnold S, Young J, Walsh MD, Jass J, Macrae F, Antill Y, Winship IM, Giles GG, Goldblatt J, Parry S, Suthers G, Leggett B, Butz M, Aronson M, Poynter JN, Baron JA, Le Marchand L, Haile R, Gallinger S, Hopper JL, Potter J, de la Chapelle A, Vasen HF, Dunlop MG, Thibodeau SN, Jenkins MA: Risks of Lynch syndrome cancers for MSH6 mutation carriers. J Nat/ Cancer Inst 2010, 102:193-201.

10. Scott RJ, McPhillips M, Meldrum CJ, Fitzgerald PE, Adams K, Spigelman AD, du Sart D, Tucker K, Kirk J: Hereditary nonpolyposis colorectal cancer in 95 families: differences and similarities between mutation-positive and mutation-negative kindreds. Am J Hum Genet 2001, 68:118-127.

11. Win AK, Young JP, Lindor NM, Tucker KM, Ahnen DJ, Young GP, Buchanan DD, Clendenning M, Giles GG, Winship I, Macrae FA, Goldblatt J, Southey MC, Arnold J, Thibodeau SN, Gunawardena SR, Bapat B, Baron JA, Casey G, Gallinger S, Marchand LL, Newcomb PA, Haile RW, Hopper JL, Jenkins MA: Colorectal and other cancer risks for carriers and noncarriers from families with a DNA mismatch repair gene mutation: a prospective cohort study. J Clin Oncol 2012, 30:958-964.

12. Vasen HF, Mecklin JP, Khan PM, Lynch HT: The International Collaborative Group on Hereditary Non-Polyposis Colorectal Cancer (ICG-HNPCC). Dis Colon Rectum 1991, 34:424-425.

13. da Silva FC, de Oliveira LP, Santos EM, Nakagawa WT, Aguiar Junior S, Valentin MD, Rossi BM, de Oliveira Ferreira F: Frequency of extracolonic tumors in Brazilian families with Lynch syndrome: analysis of a hereditary colorectal cancer institutional registry. Fam Cancer 2010, 9:563-570

14. Muller A, Edmonston TB, Corao DA, Rose DG, Palazzo JP, Becker H, Fry RD, Rueschoff J, Fishel R: Exclusion of breast cancer as an integral tumor of hereditary nonpolyposis colorectal cancer. Cancer Res 2002, 62:1014-1019.

15. Risinger JI, Barrett JC, Watson P, Lynch HT, Boyd J: Molecular genetic evidence of the occurrence of breast cancer as an integral tumor in patients with the hereditary nonpolyposis colorectal carcinoma syndrome. Cancer 1996, 77:1836-1843.

16. de Leeuw WJ, van Puijenbroek M, Tollenaar RA, Cornelisse CJ, Vasen HF, Morreau H: Correspondence re: A. Muller et al., Exclusion of breast cancer as an integral tumor of hereditary nonpolyposis colorectal cancer. Cancer Res., 62: 1014-1019, 2002. Cancer Res 2003, 63:1148-1149.

17. Shanley S, Fung C, Milliken J, Leary J, Barnetson R, Schnitzler M, Kirk J: Breast cancer immunohistochemistry can be useful in triage of some HNPCC families. Fam Cancer 2009, 8:251-255.

18. Jensen UB, Sunde L, Timshel S, Halvarsson B, Nissen A, Bernstein I, Nilbert M: Mismatch repair defective breast cancer in the hereditary nonpolyposis colorectal cancer syndrome. Breast Cancer Res Treat 2010, 120:777-782.

19. Walsh MD, Buchanan DD, Cummings MC, Pearson SA, Arnold ST, Clendenning M, Walters R, McKeone DM, Spurdle AB, Hopper JL, Jenkins MA, Phillips KD, Suthers GK, George J, Goldblatt J, Muir A, Tucker K, Pelzer E, Gattas MR, Woodall S, Parry S, Macrae FA, Haile RW, Baron JA, Potter JD, Le Marchand L, Bapat B, Thibodeau SN, Lindor NM, McGuckin MA, Young JP: Lynch syndrome-associated breast cancers: clinicopathologic characteristics of a case series from the colon cancer family registry. Clin Cancer Res 2010, 16:2214-2224.

20. Adem C, Soderberg CL, Cunningham JM, Reynolds C, Sebo TJ, Thibodeau SN, Hartmann LC, Jenkins RB: Microsatellite instability in hereditary and sporadic breast cancers. Int J Cancer 2003, 107:580-582.

21. Yee CJ, Roodi N, Verrier CS, Parl FF: Microsatellite instability and loss of heterozygosity in breast cancer. Cancer Res 1994, 54:1641-1644.

22. Nystrom-Lahti M, Kristo P, Nicolaides NC, Chang SY, Aaltonen LA, Moisio AL, Jarvinen HJ, Mecklin JP, Kinzler KW, Vogelstein B: Founding mutations and Alu-mediated recombination in hereditary colon cancer. Nat Med 1995, 1:1203-1206

23. Gylling A, Abdel-Rahman WM, Juhola M, Nuorva K, Hautala E, Jarvinen HJ, Mecklin JP, Aarnio M, Peltomaki P: Is gastric cancer part of the tumour spectrum of hereditary non-polyposis colorectal cancer? A molecular genetic study. Gut 2007, 56:926-933.

24. Gylling $A H$, Nieminen TT, Abdel-Rahman WM, Nuorva $K$, Juhola M, Joensuu El, Jarvinen HJ, Mecklin JP, Aarnio M, Peltomaki PT: Differential cancer predisposition in Lynch syndrome: insights from molecular analysis of brain and urinary tract tumors. Carcinogenesis 2008, 29:1351-1359.

25. Joensuu El, Abdel-Rahman WM, Ollikainen M, Ruosaari S, Knuutila S, Peltomaki $P$ : Epigenetic signatures of familial cancer are characteristic of tumor type and family category. Cancer Res 2008, 68:4597-4605.

26. Isola J, DeVries S, Chu L, Ghazvini S, Waldman F: Analysis of changes in DNA sequence copy number by comparative genomic hybridization in archival paraffin-embedded tumor samples. Am J Pathol 1994, 145:1301-1308

27. Boland CR, Thibodeau SN, Hamilton SR, Sidransky D, Eshleman JR, Burt RW Meltzer SJ, Rodriguez-Bigas MA, Fodde R, Ranzani GN, Srivastava S: A National Cancer Institute Workshop on Microsatellite Instability for cancer detection and familial predisposition: development of international criteria for the determination of microsatellite instability in colorectal cancer. Cancer Res 1998, 58:5248-5257.

28. Renkonen E, Zhang Y, Lohi H, Salovaara R, Abdel-Rahman WM, Nilbert M, Aittomaki $\mathrm{K}$, Jarvinen HJ, Mecklin JP, Lindblom A, Peltomaki P: Altered expression of $\mathrm{MLH} 1, \mathrm{MSH} 2$, and $\mathrm{MSH} 6$ in predisposition to hereditary nonpolyposis colorectal cancer. J Clin Oncol 2003, 21:3629-3637.

29. MRC-Holland MLPA. [http://www.mrc-holland.com/WebForms/ WebFormMain.aspx].

30. Nygren AO, Ameziane N, Duarte HM, Vijzelaar RN, Waisfisz Q, Hess CJ, Schouten JP, Errami A: Methylation-specific MLPA (MS-MLPA): simultaneous detection of CPG methylation and copy number changes of up to 40 sequences. Nucleic Acids Res 2005, 33:e128.

31. Jeuken JW, Cornelissen SJ, Vriezen M, Dekkers MM, Errami A, Sijben A, Boots-Sprenger SH, Wesseling P: MS-MLPA: an attractive alternative laboratory assay for robust, reliable, and semiquantitative detection of MGMT promoter hypermethylation in gliomas. Lab Invest 2007, 87:1055-1065.

32. VassarStats: Website for Statistical Computation. [http://vassarstats.net/].

33. Ikpatt OF, Kuopio T, Ndoma-Egba R, Collan Y: Breast cancer in Nigeria and Finland: epidemiological, clinical and histological comparison. Anticancer Res 2002, 22:3005-3012.

34. Vasen HF: Clinical description of the Lynch syndrome [hereditary nonpolyposis colorectal cancer (HNPCC)]. Fam Cancer 2005, 4:219-225.

35. Foulkes WD: Inherited susceptibility to common cancers. N Engl J Med 2008, 359:2143-2153. 
36. Lynch HT, Krush AJ: Cancer family "G" revisited: 1895-1970. Cancer 1971, 27:1505-1511

37. Park JG, Park YJ, Wijnen JT, Vasen HF: Gene-environment interaction in hereditary nonpolyposis colorectal cancer with implications for diagnosis and genetic testing. Int J Cancer 1999, 82:516-519.

38. Chao EC, Lipkin SM: Molecular models for the tissue specificity of DNA mismatch repair-deficient carcinogenesis. Nucleic Acids Res 2006 34:840-852.

39. Esteller M, Corn PG, Baylin SB, Herman JG: A gene hypermethylation profile of human cancer. Cancer Res 2001, 61:3225-3229.

40. Geary J, Sasieni P, Houlston R, Izatt L, Eeles R, Payne SJ, Fisher S, Hodgson SV: Gene-related cancer spectrum in families with hereditary non-polyposis colorectal cancer (HNPCC). Fam Cancer 2008, 7:163-172.

41. Koninki K, Tanner M, Auvinen A, Isola J: HER-2 positive breast cancer: decreasing proportion but stable incidence in Finnish population from 1982 to 2005. Breast Cancer Res 2009, 11:R37.

42. Wimmer K, Etzler J: Constitutional mismatch repair-deficiency syndrome: have we so far seen only the tip of an iceberg? Hum Genet 2008, 124:105-122.

43. Cejka P, Stojic L, Mojas N, Russell AM, Heinimann K, Cannavo E, di Pietro M, Marra $G$, Jiricny J: Methylation-induced $G(2) / M$ arrest requires a full complement of the mismatch repair protein hMLH1. EMBO J 2003, 22:2245-2254

44. Woerner SM, Benner A, Sutter C, Schiller M, Yuan YP, Keller G, Bork P, Doeberitz MK, Gebert JF: Pathogenesis of DNA repair-deficient cancers: a statistical meta-analysis of putative Real Common Target genes. Oncogene 2003, 22:2226-2235.

45. Zhang S, Lloyd R, Bowden G, Glickman BW, de Boer JG: Msh2 DNA mismatch repair gene deficiency and the food-borne mutagen 2-amino1-methy1-6-phenolimidazo [4,5-b] pyridine (PhIP) synergistically affect mutagenesis in mouse colon. Oncogene 2001, 20:6066-6072.

46. Zlatanou A, Despras E, Braz-Petta T, Boubakour-Azzouz I, Pouvelle C, Stewart GS, Nakajima S, Yasui A, Ishchenko AA, Kannouche PL: The hMsh2hMsh6 complex acts in concert with monoubiquitinated PCNA and Pol eta in response to oxidative DNA damage in human cells. Mol Cell 2011, 43:649-662.

47. Verma M, Srivastava S: Epigenetics in cancer: implications for early detection and prevention. Lancet Oncol 2002, 3:755-763.

48. Buyru N, Altinisik J, Ozdemir F, Demokan S, Dalay N: Methylation profiles in breast cancer. Cancer Invest 2009, 27:307-312

49. Aktan-Collan K, Haukkala A, Mecklin JP, Uutela A, Kaariainen H: Psychological consequences of predictive genetic testing for hereditary non-polyposis colorectal cancer (HNPCC): a prospective follow-up study. Int J Cancer 2001, 93:608-611.

50. Bryant $\mathrm{H}$, Mai V: Impact of age-specific recommendation changes on organized breast screening programs. Prev Med 2011, 53:141-143.

doi:10.1186/bcr3205

Cite this article as: Lotsari et al.: Breast carcinoma and Lynch syndrome: molecular analysis of tumors arising in mutation carriers, non-carriers, and sporadic cases. Breast Cancer Research 2012 14:R90.

\section{Submit your next manuscript to BioMed Central and take full advantage of:}

- Convenient online submission

- Thorough peer review

- No space constraints or color figure charges

- Immediate publication on acceptance

- Inclusion in PubMed, CAS, Scopus and Google Scholar

- Research which is freely available for redistribution

Submit your manuscript at www.biomedcentral.com/submit
Ciomed Central 